DOI 10.31558/2519-2949.2020.2.3

УДК 323.2

ORCID ID: https://orcid.org/0000-0001-5421-0271

Нагорняк Т. Л., Донецький національний університет імені Василя Стуса

ORCID ID: https://orcid.org/0000-0002-7916-0490

Зайченко І. А., Донецький національний університет імені Василя Стуса

\title{
СТАВЛЕННЯ УКРАЇНЦІВ ДО ЗБРОЙНОГО КОНФЛІКТУ ЯК ЧИННИК СТРИМУВАНЬ І ПРОТИВАГ У ПРОЦЕСІ СТАНОВЛЕННЯ ІНСТИТУТУ НАРОДОВЛАДДЯ В УКРАЇНІ
}

У статті здійснено спробу наукового обтрунтування реальною політичною практикою динаміки змін громадської думки щьоо конфліктогенності украӥнської реальності через систему стримувань і противаг у контексті становлення інституту народовладдя в Украӥні.

Висловлені авторками висновки обумовлені Постановою ВРУ №727-ІХ від 18.06.2020 p. $i$ трунтуються на матеріалах опитувань та соиіологічних дослідженнях Інституту соціологіі НАН України, Фонду «Демократичні ініиіативи» ім. Ілька Кучеріва, Центру Разумкова, Київського міжнародного інституту соџіологї, чинному законодавстві та власному досвіді прикладного політичного аналізу й політичного консультування.

Охарактеризовано ключові тенденції суспільних настроїв щодо збройного конфлікту на Сході України, щзо залишаються в иілому сталими впродовж 2014 - 2020 рр. А саме: визнання «російського фактору» у конфлікті, критична оиінка громадянами держсвної політики України щуодо врегулювання та соціально-гуманітарної роботи з тимчасово окупованими територіями, бачення майбутнього політико-правового статусу т.зв. «ДНР-ЛНР» у складі Украйни, з огляду на неможливість повномасштабного військового наступу, з одного боку, і готовність йти на компроміси заради мирного врегулювання, з іншого. Доведено, щьо збройний конфлікт на Донбасі на сьогодні не потрапляє в топ найважливіших для украӥнців проблем (на відміну від 2014-2015 рр.) і тяжіє до заморожування і підтримки сторонами конфлікту існуючого status quо. Проте, його гібридність створюватиме в Україні джерело політичної нестабільності і поле для маніпуляиій суспільством з боку держави. Визнається, щио мирне врегулювання збройного конфлікту на Сході України за сучасної політичної кон 'юнктури можливе лише зі значними поступками національними інтересами України. Доведено, щзо інституціоналізаиія народовладдя в Україні через обов'язковий всеукраӥнський референдум, враховуючи низький рівень правосвідомості та аналіз емпірики, $\epsilon$ передчасною.

Ключові слова: громадська думка, система стримувань і противаг, народовладдя в Украӥні, збройний конфлікт, Донбас, Схід України, «політика знизу».

Випробування російською агресією, світовою рецесією, епідемією, та внутрішньою системною кризою актуалізують питання зрілості взаємовідносин Держави і Суспільства в Україні. Одним 3 механізмів організації їх публічного діалогу здатна виступати система стримувань і противаг. Широкі повноваження народу i прямий його вплив шляхом всеукраїнського референдуму на законодавчий процес в державі та реалізацію повноважень владними інститутами - один з елементів системи стримувань і противаг в функціонуванні законодавчої, судової і виконавчої влади України. Вивчення громадської думки, за таких умов як інструменту втримання балансу ініціатив та ефективності соціального контракту держави і суспільства, самоідентифікація громадян, їх ставлення до ключових подій і персон $є$ тим чинником, що здатний виступати як силою стратифікації, так і силою вирівнювання у процесах розвитку України.

Народовладдя, як концепт, є ключовим у теорії прямої демократії, без чого неможливо уявити побудову громадянського суспільства та правової держави. За сучасних умов розвитку політичних систем, що декларують себе демократичними, народовладдя трактується як невід'ємна частина народного суверенітету та конституційний принцип. Так, відповідно до Конституції України, саме 
український народ делегував частину своєї природної свободи на користь державної влади та наділив державу повноваженням, констатує український дослідник О. Петришин [14, с. 20-21]. Аналіз публікацій, присвячених теоретико-методологічним засадам реалізації народовладдя в Україні, довів, що найбільш доцільним до нашої наукової розробки $\epsilon$ розуміння Ф. В. Веніславським реального народовладдя. Він бачить його як універсальний політико-правовий принцип сучасного конституціоналізму, що є невід'ємною складовою системи загальновизнаних конституційних цінностей та у своїй сукупності становлять засади демократичного конституційного ладу України [4, с. 48]. Зрозумілим є факт, що безпосередня демократія - це природнє право народу, вона з'явилася раніше за представницьку. I сьогодні народовладдя реалізується безпосередньо народом і через представницькі органи влади, яким народ делегував таке право на підставі Конституції та спеціальних нормативних актів. Досліджуючи теоретико-правові аспекти аналізу реалізації права на спротив та інших форм народовладдя в Україні, Г. Гайду дійшла висновку, що політико-правові практики впровадження реального народовладдя в Україні демонструють незрілість правової культури суспільства (у тому числі й суб'єктів влади) та безпорадність правових інституцій через їх політизованість. Тому важливим $\epsilon$ пошук тих інструментів підвищення ефективності реалізації реального народовладдя, які б задовільнили б і державу, і суспільство [7]. Одним 3 таких інструментів $\epsilon$ вивчення думки громадян і введення громадянської освіти на всіх рівнях соціалізації індивіда.

Ставлення українців до збройного конфлікту, що вже шостий рік поспіль триває, є силою стратифікації українського суспільства, роз'єднавши громадян по осі «за Мир, особливий статус територій і компроміси з РФ», «за Перемогу України», «за Україну без Донбасу» тощо. За таких умов відтворення механізму стримувань і противаг має взяти на себе Держава. У першу чергу, Президент (Головнокомандуючий, Голова РНБОУ, Гарант Конституції України), озвучивши чітку позицію Держави і дотримуючись послідовно ії в своїх діях та рішеннях. Національні інтереси і суверенність держави - цінності і підстави для такої позиції. За умов відсутності оприлюдненої і дієвої державної стратегії розв'язання збройного конфлікту з боку України, крихкості монобільшості в парламенті, неприйнятої програми Уряду та мінливості персон на ключових посадах держави, очікувати від державних органів влади консолідаційної політики не слід.

Враховуючи вищеозначену ситуацію, коли «низи не можуть, а верхи не хочуть», вивчення динаміки ставлень українців до російсько-української війни дозволить зрозуміти реперні точки, навколо яких слід будувати «політику знизу», де влада виступатиме простими функціонерами, а консолідація громад, інтелектуалів, органів місцевого самоврядування і малого з середнім бізнесом дозволить вийти на новий рівень публічного діалогу Суспільства і Держави.

Як свідчать дані системних досліджень громадської думки до 2013 р., в Україні існувало кілька ключових чинників, що ділили суспільство: мова спілкування та ставлення до статусу російської мови, а також зовнішньополітичний вектор держави: євроінтеграція чи реверс з Росією та країнами СНД [2, с. 12]. Не можна не погодитися з твердженням Ірини Бекешкіної, що політично ці реальні відмінності були вперше використані під час президентських виборів 2004 р., коли активно пропагувалася теза про поділ України [Там само, с. 13]. У контексті сучасних подій вони стали ідеологічним підгрунтям для російського сценарію демонтажу української державності: маніпуляції громадською думкою, спотворення історичної пам'яті і створення паралельної системи «споконвічних» цінностей у контексті концепції «Новоросія»- i, як результат, російська анексія АР Крим та збройний конфлікт на Сході України.

Meта статmі - на прикладі динаміки змін громадської думки щодо збройного конфлікту на Сході України та очікуваних громадянами шляхів подолання його наслідків, зрозуміти рівень готовності українців до реалізації народовладдя шляхом обов'язкового всеукраїнського референдуму, що здатний стати ключовим інструментом системи стримувань і противаг по осі Держава - Суспільство / Влада - Народ.

Емпіричним матеріалом для здійснення аналізу динаміки змін настроїв українців щодо збройного конфлікту на Сході України стала низка опитувань і соціологічних досліджень, що проводилися Інститутом соціології НАН України (щорічний випуск видання «Українське суспільство: моніторинг соціальних змін»), Фондом «Демократичні ініціативи» ім. Ілька Кучеріва (далі - Фонд «Демініціативи»), Центром Разумкова, Київським міжнародним інститутом соціології (далі - КМІС). Наукова розробка проблеми представляється нині однією з найактуальніших, адже сам збройний конфлікт знаходиться в епіцентрі подій великої практичної значущості. У доробку українського соціолога, директора Фонду «Демініціативи» у 2001-2020 рр. Ірини Бекешкіної [2] 
понад 100 праць з проблеми вивчення тенденцій громадської думки щодо найважливіших політичних процесів всередині країни, зокрема реформ у ключових сферах, а також проблеми комунікації держави з прифронтовими територіями Донбасу. Вивченням громадської думки щодо тих чи інших процесів займаються вітчизняні науковці: Анатолій Ручка [18], Ігор Бураковський [3], Марія Золкіна [12] та інші. Проте, на наше переконання, питання динаміки настроїв українців щодо збройного конфлікту на Донбасі і бачення шляхів його вирішення вимагає окремої наукової розвідки.

Однією з найважливіших особливостей досліджуваної проблеми є достатньо вільне трактування суспільством, експертами i політикумом подій на Сході України: сепаратистський заколот, громадянська війна, російська військова агресія, російсько-українська війна. Не беручи до уваги кон'юнктурний контекст, в якому повсякчас по-різному називаються ці події, слід констатувати: 3 точки зору міжнародного права і політичної науки доцільно використовувати категорію «збройний конфлікт».

Загальноприйнятим є визначення збройного конфлікту, надане уЖеневських конвенціях i Додаткових протоколах до них (ст. 1). Збройний конфлікт - це:

- конфлікт між двома або більше державами (міжнародний збройний конфлікт);

- конфлікт, при якому збройні сили держави або інші збройні угрупування контролюють частину державної території, що дає їм змогу здійснювати безперервні та погоджені воєнні дії (неміжнародний збройний конфлікт) [10].

Воєнна доктрина України у редакції від 24 вересня 2015 р. кваліфікує збройний конфлікт як «збройне зіткнення між державами (міжнародний збройний конфлікт, збройний конфлікт на державному кордоні) або між ворогуючими сторонами в межах території однієї держави, як правило, за підтримки ззовні (внутрішній збройний конфлікт)» [6]. Відповідно до цього визначення, події, що відбуваються вже шість років на Сході України, можуть кваліфікуватися як внутрішній збройний конфлікт за всебічної підтримки (військової, політичної, гуманітарної тощо) Російської Федерації. Проте, саме у контексті українсько-російського конфлікту політична наука ввела у науковий обіг концепцію гібридної війни.

Гібридність цього збройного конфлікту виявляється не стільки у територіальних домаганнях Росії (як у випадку анексії АР Крим), скільки устворенні осередку перманентної політичної нестабільності для всієї Української держави: «вживляння» в Україну «ДНР-ЛНР» у нинішньому вигляді для дезінтеграції української державності, блокування курсу до ЄС і НАТО, встановлення підконтрольності та підпорядкованості України Росії [18, с. 212]. Більш того, гібридна війна створює постійне поле для дискусій і політичних маніпуляцій громадською думкою щодо самого збройного конфлікту та можливих шляхів його вирішення і подолання наслідків.

Як свідчать результати дослідження політичних підсумків 2015 року, проведеного Фондом «Демініціативи» та КМІС, 78.5\% громадян України назвали головними завданнями влади врегулювати ситуацію на Донбасі та досягти миру [1].

Зауважимо, що каталізатором такого утримання фокусу громадської уваги впродовж 20142015 рр. на збройному конфлікті на Сході України була низка чинників. Анексія АР Крим у лютомуберезні 2014 р., початок боїв за Донецький аеропорт у травні 2014 р. (завершилися у січні 2015 р.), Іловайський і Дебальцевський «котли» за прямої фізичної участі російських збройних сил, сотні тисяч переселенців і відповідна часу риторика офіційного Києва і міжнародної спільноти сформували в суспільстві відповідну агенду з пролонгованим терміном дії.

Проте, протягом наступних років тема збройного конфлікту на Донбасі як комплексна проблема військового, політичного, економічного і гуманітарного гатунку практично зникла 3 офіційного дискурсу і розфокусувалася на складові. Це створює певний дисонанс: адже наче і відбуваються позитивні зрушення (наприклад, обмін військовополоненими восени 2019 р.), проте в цілому конфлікт заморожується. Так у соціологічних дослідженнях щодо підсумків 2019 року, тема збройного конфлікту на Сході України, як самостійна і ключова проблема держави, не звучала взагалі. Її компоненти, як то: звільнення полонених, нормандська зустріч, розведення військ на Донбасі важливими для політичного року 2019 назвали лише 8, 5 і 2\% опитаних відповідно [15]. Зневіра українців у зрушеннях на Східному напрямі досягла своєї критичної позначки: встановлення миру на Донбасі назвали імовірним лише 42\%. Натомість $46 \%$ респондентів визнали, що це неможливо [Там само]. На нашу думку, за цифрою 46\% криється більш глибока катастрофа України: на життя майже половини населення цей конфлікт і його наслідки не впливають, а сформована за ці роки політична реальність стала цілком прийнятною. 
Характеризуючи динаміку громадських настроїв за 2014 - 2020 рр. стосовно збройного конфлікту на Сході України, слід відзначити такі тенденції, що зберігаються впродовж названого періоду.

Очевидним для більшості громадян України $\epsilon$ «російський фактор» збройного конфлікту на Донбасі. При цьому з 2015 р. зросла кількість тих, хто сприймає конфлікт як війну між Україною i Росією: $28 \%$ у 2015 р. - 35,2\% у 2018 р. [5, с. 112]. Можна припустити, що таке розуміння ситуації на Сході України відбулося за рахунок зменшення частки тих, хто розцінював його як сепаратистський заколот, підтриманий Москвою: 31,5\% у 2015 р. проти 25,6\% у 2018 р. [Там само]. При цьому, найчастіше українці оцінюють так звані «ДНР-ЛНР» як терористичні організації, підтримувані Росією або російські окупаційні адміністрації в Україні.

Напередодні президентських виборів 2019 р. аналітик Фонду «Демініціативи» Сергій Шаповалов оприлюднив результати дослідження, відповідно до яких $72 \%$ громадян України поділяли думку, що зараз триває війна Росії з Україною [17]. Загрозливими у цьому контексті виглядають погляди мешканців підконтрольної Україні території Донбасу, що розділилися практично навпіл: 39\% вважали, що триває війна Росії з Україною, а 40\% - що ні [Там само]. А основну провину за збройний конфлікт мешканці підконтрольних територій Донецької і Луганської областей покладали на чинну українську владу (57\%), ще 33\% звинувачували владу попереднього режиму В. Януковича, 24\% - Майдан [15].

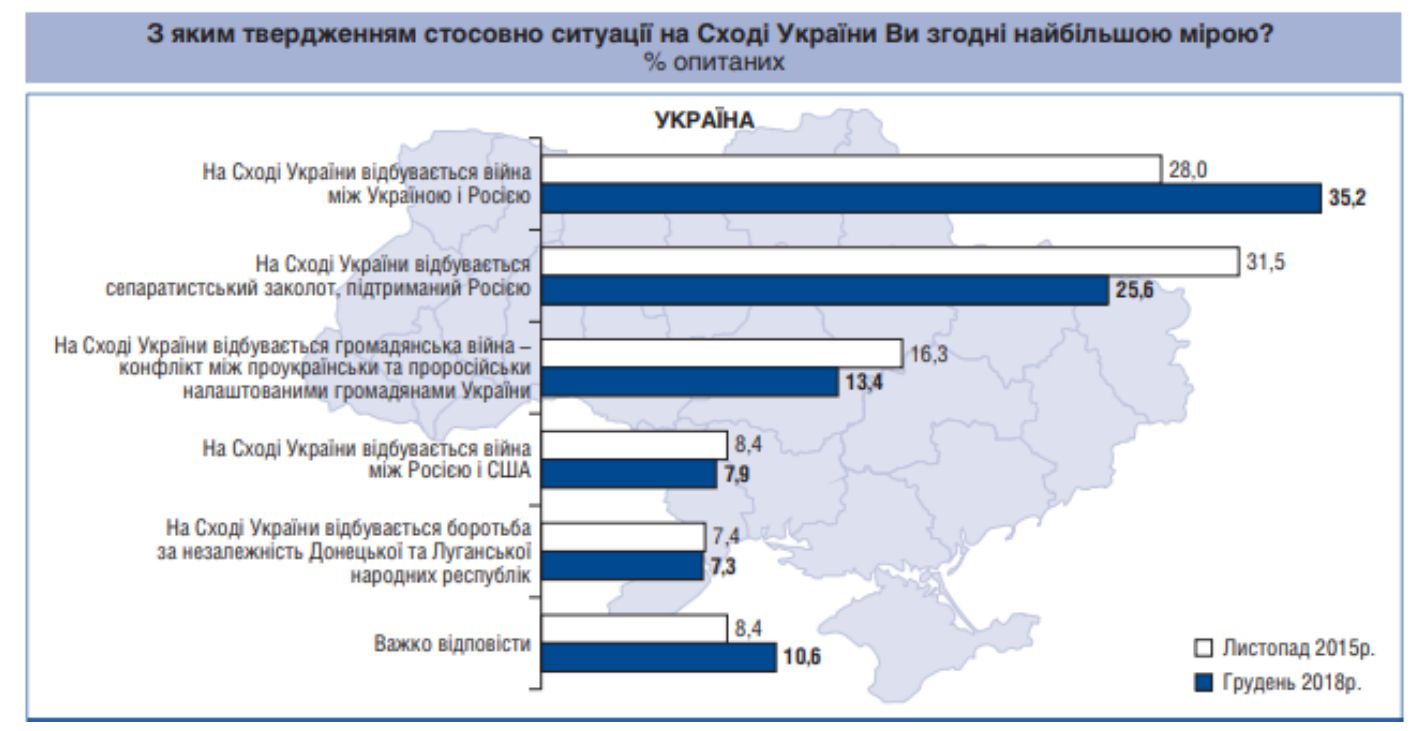

\section{Рис. 1. Ситуація на Донбасі очима громадян Украӥни. Соціологічне дослідження Центру Разумкова. Грудень 2018 р. [5, c. 111].}

Отже, очікувано трансльований на вищому державному рівні меседж про «втому від війни», а також більш нагальні для повсякденного життя проблеми фінансово-економічної кризи, корупції, ціноутворення на енергоносії тощо і далі позначатимуться на настроях українців щодо збройного конфлікту на Донбасі.

Ще однією тенденцією громадських настроїв нами вбачається загалом критична оцінка громадянами політики України з врегулювання збройного конфлікту.

Більшість українців не вважають іï ефективною, послідовною, виваженою, зрозумілою для суспільства та країн-партнерів. Зокрема, вкрай неоднозначні оцінки отримали мирні ініціативи України в рамках Мінського переговорного процесу. Близько третини українців $(30,2 \%)$ оцінили результати Мінських домовленостей негативно і ще близько третини (32,6\%) - нейтрально [20]. При цьому майже третина громадян України взагалі нічого про них не знає.

Переважна більшість населення (55\%) не менш неефективною вважають участь Заходу у врегулюванні конфлікту на Сході України [19]. Зокрема, йдеться про роботу місії ОБСЄ, впливу міжнародних санкцій на російську зовнішню політику тощо. Загалом можна констатувати, що за браком власної чіткої стратегії дій на донбаському напрямі Україна перетворилася за роки переговорного процесу з його учасника на розмінну карту, якою Західна Європа намагається втримати імперський апетит Росії. 
Не менш показовими представляються тенденції змін громадської думки стосовно перспектив мирного врегулювання на Сході України. Оцінюючи у лютому 2020 р. майбутнє Донбасу, більшість громадян (54\%) хотіли б, щоб ці території повернулися до складу Донецької та Луганської областей України на тих же умовах, що були раніше [8]. Для порівняння станом на 2015 р. політичне майбутне «ДНР» та «ЛНР» у складі Донецької і Луганської областей на тих самих умовах, що й до конфлікту, вбачали 49\% опитаних [1]. У той же час 22\% громадян у 2015 р. порівняно з $13 \%$ у 2020 р. були згодні, аби окуповані території повернулися під юрисдикцію України з більшим обсягом незалежності від центральної влади [12, с. 176].

Зауважимо також, що за п'ять років (2015 - 2020 рр.) незначно, проте зросла частка тих, хто підтримує встановлення миру на Донбасі силовим шляхом: 14\% у 2015 р. і 20\% громадян у 2020 р. (проти цього виступають 56\%) [16].

Окремо слід відзначити тенденцію до готовності українців іти на компроміси, але неприйняття концепції «миру за будь-яку ціну» або «миру в обмін на території» (лише $10 \%$ нас підтримали б визнання Криму російською територією в обмін на звільнення Донбасу, не підтримують таку позицію 70\% українців [8]). Слід наголосити, що у випадку обговорюваної у суспільстві формули «Криму в обмін на Донбас» йдеться скоріше про емоційну реакцію українців на багаторічний збройний конфлікт, а не про реальну готовність поступитися своїми територіями. Також доволі дискусійними виглядають спроби змоделювати майбутню кримськотатарську автономію в Криму (проєкт доцента кафедри культурології НаУКМА Ігоря Лосєва [13]), адже об'єктивно Україна втратила свій суверенітет в цій автономній республіці. Однак, законодавець чітко визначив, що «тимчасова окупація Російською Федерацією територій України, (...), незалежно від ії тривалості $€$ незаконною і не створює для Російської Федерації жодних територіальних прав» (ст. 2 Закону України «Про особливості державної політики із забезпечення державного суверенітету України на тимчасово окупованих територіях у Донецькій та Луганській областях») [11].

Повертаючись до суспільних настроїв щодо майбутнього повернення ОРДЛО, зауважимо, що загалом не підтримується ідея закріплення в Конституції України «особливого статусу» Донбасу, запровадження федеративного устрою України, інтеграції до України так званих «ДНР-ЛНР» у нинішньому вигляді. Більш того, найменш прийнятними для громадян України, причому в усіх регіонах, $\epsilon$ :

- проведення виборів на умовах бойовиків;

Неприйнятно

$66 \%$

$61 \%$

$58 \%$

$54 \%$
Прийнятно

$13 \%$

$15 \%$

$18 \%$

$30 \%$

- внесення змін до Конституції щодо надання російській мові статусу державної мови [16].

Також можна з упевненістю сказати про неготовність українців відмовитися від зовнішньополітичного курсу в бік євроінтеграції та вступу до НАТО. А от введення миротворчих сил ООН на тимчасово окуповані території підтримали більше 58\% громадян [9]. Причому найчастіше українці відзначали, що миротворчі сили мають взяти під контроль усю окуповану територію, включно з ділянкою українсько-російського кордону.

Насамкінець, уконтексті визначення динаміки змін настроїв українців щодо збройного конфлікту слід виокремити наступні показові результати: громадяни України з розумінням ставляться до людей, які залишилися на окупованих територіях. Найчастіше їх оцінюють або як заручників обставин (29\%), або заручників дій незаконних збройних формувань (27\%). Лише кожен десятий вважає їх зрадниками, які свідомо перейшли на бік ворога [5].

У той же час соціально-гуманітарна політика Києва щодо окупованих територій кваліфікується неоднозначно. Зокрема, це стосується питання про соціальні та пенсійні виплати громадянам на непідконтрольних територіях і спрощення перетину лінії розмежування [3, с. 82]. Водночас позитивним надбанням української нації за роки збройного конфлікту слід вважати підтримку абсолютною більшістю громадян необхідності допомагати жителям Донбасу, які прагнуть виїхати на контрольовану Україною територію, а також максимально спрощувати для дітей доступ до навчання в українських освітніх закладах. 


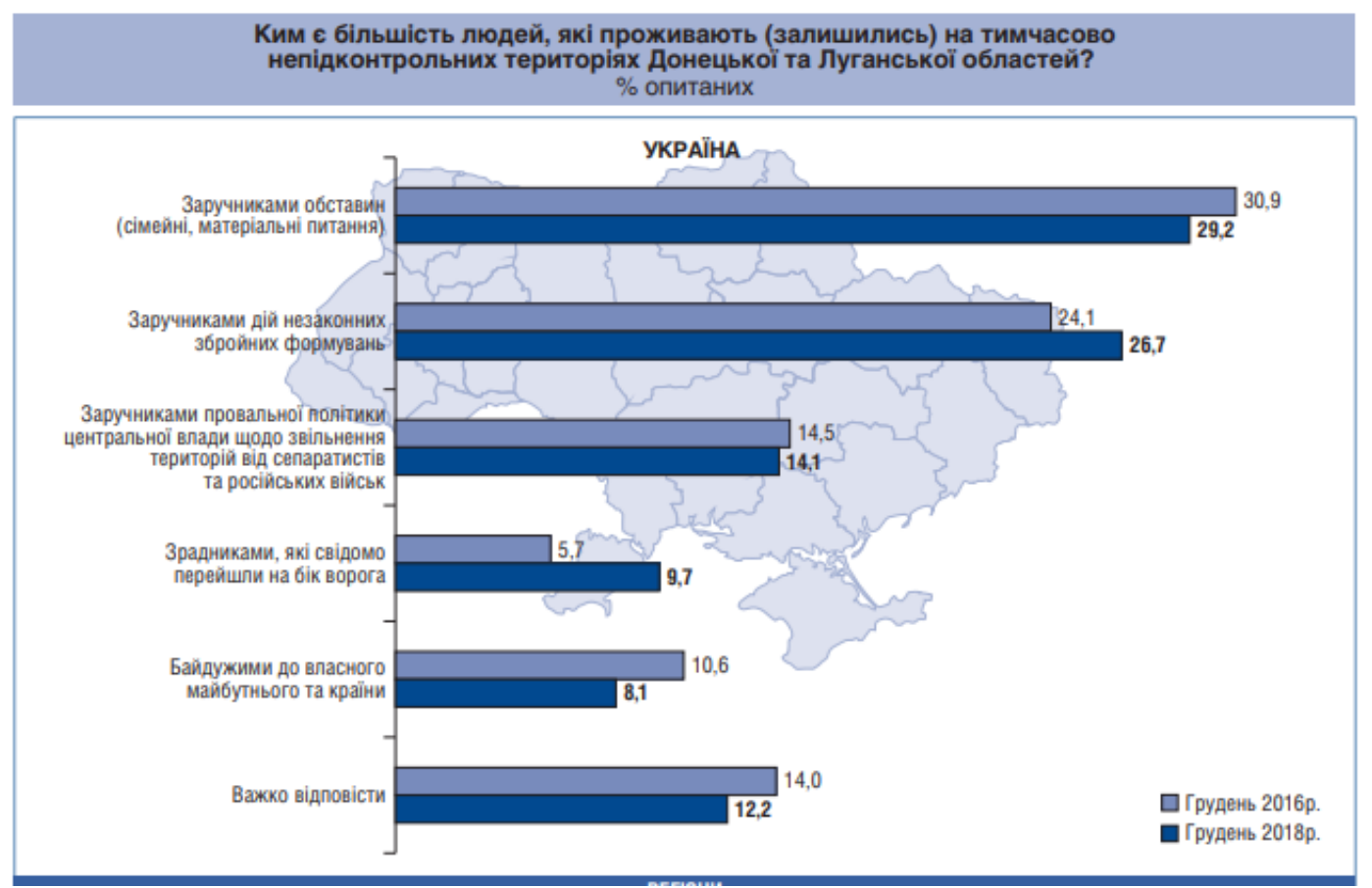

Рис. 2. Ситуація на Донбасі очима громадян Украӥни. Соціологічне дослідження Центру Разумкова. Грудень 2018 р. [5, с. 116].

Отже, здійснена наукова розвідка підтверджує, що коливання суспільних настроїв щодо тих чи інших соціально-політичних проблем $є$ прямим, хоч i не абсолютно залежним, результатом державної політики (внутрішньої і зовнішньої). Більш того, громадська думка $\epsilon$ лакмусовим папірцем стану готовності українців до обов'язкового всеукраїнського референдуму, питаннями якого можуть стати територія і державні кордони України, державний суверенітет, політичні практики єднання держави-нації. Аналіз динаміки громадської думки демонструє відсутність консолідованої позиції українців щодо зовнішнього вектору державної політики та внутрішніх політичних практик навколо національних інтересів і державницьких цінностей. Це означає, що ефективна система стримувань i противаг в частині реалізації народовладдя в Україні i відповідальний вибір народу залишається відкритим питанням. Як i те, кому потрібно запровадження обов'язкового всеукраїнського референдуму в таких умовах. Очікуваним $\epsilon$ заморожування збройного конфлікту на Сході України разом з поступовим зникненням проблеми 3 міжнародного порядку денного та офіційного дискурсу влади. А готовність громадян іти на болючі компроміси заради миру, попри колосальні людські жертви за $2014-2020$ рр., значні втрати людського капіталу у перспективі (в сенсі жителів ОРДЛО, що ціннісно ближчі до Росії) та економічний баласт, який представлятиме собою нині окупований Донбас, - свідчать про можливості мирного врегулювання лише у довгостроковій перспективі i, вірогідно, всупереч національним інтересам України.

\section{Бібліографічний список:}

1. 2015-й: політичні підсумки - думка населення. Дослідження Фонду «Демократичні ініціативи» ім. Ілька Кучеріва та Київського міжнародного інституту соціології. 29.12.2015.

URL: https://dif.org.ua/article/2015-y-politichni-pidsumki-dumka-naselennya

2. Бекешкіна I. Вирішальний 2014-й: роз'єднав чи з'єднав Україну? Трансформація суспільних настроїв в умовах протидії агресії Росії на Донбасі: регіональний вимір / Наук. ред. О. Гарань. К.: Стилос, 2017. С. 8-39.

3. Бураковський I. Російська агресія на Сході України як чинник формування економічних настроїв в Україні. Трансформація суспільних настроїв в умовах протидії агресії Росії на Донбасі: регіональний вимір / Наук. ред. О. Гарань. К.: Стилос, 2017. С. 70-111.

4. Веніславський Ф. Ідея народовладдя в теорії та практиці українського державотворення (соціальноправова цінність ідеї народовладдя) // Вісник Конституційного Суду України. 2011. № 3. С. 48-56.

5. Війна на Донбасі: реалії і перспективи врегулювання. Центр Разумкова. Проєкт «Конфлікт на Донбасі: сучасні реалії і перспективи врегулювання» за підтримки МЗС Нідерландів. К., 2019. 144 с.

6. Воєнна доктрина України. Затверджено Указом Президента України від 24 вересня 2015 року № 555/2015. URL: https://zakon.rada.gov.ua/laws/show/555/2015 
7. Гайду Г. Конституційні форми реалізації народного волевиявлення через референдум та виборчий процес // Evropský politický a právní diskurz. 2018. Vol. 5. Iss. 4. P. 105-113.

8. Громадська думка про ситуацію на Донбасі та шляхи відновлення суверенітету України над окупованими територіями. Опитування Центру Разумкова. 11.10.2019. URL: http://razumkov.org.ua/napriamky/sotsiologichnidoslidzhennia/gromadska-dumka-pro-sytuatsiiu-na-donbasi-ta-shliakhy-vidnovlennia-suverenitetu-ukrainy-nadokupovanymy-terytoriiamy

9. Громадська думка про ситуацію на Донбасі та шляхи відновлення суверенітету України над окупованими територіями (лютий 2020p.). Опитування Центру Разумкова. 26.02.2020.

URL: http://razumkov.org.ua/napriamky/sotsiologichni-doslidzhennia/gromadska-dumka-pro-sytuatsiiu-na-donbasita-shliakhy-vidnovlennia-suverenitetu-ukrainy-nad-okupovanymy-terytoriiamy-liutyi-2020r

10. Додатковий протокол до Женевських конвенцій від 12 серпня 1949 року, що стосується захисту жертв збройних конфліктів неміжнародного характеру (Протокол II), від 8 червня 1977 року.

URL: https://zakon.rada.gov.ua/laws/show/995_200

11. Закон України «Про особливості державної політики із забезпечення державного суверенітету України на тимчасово окупованих територіях у Донецькій та Луганській областях». 18.01.2018.

URL: https://zakon.rada.gov.ua/laws/show/2268-19.

12. Золкіна М. Донбас: нові тренди громадської думки. Трансформація суспільних настроїв в умовах протидії агресії Росії на Донбасі: регіональний вимір / Наук. ред. О. Гарань. К.: Стилос, 2017. С. 173-198.

13. Лосєв І. Яким стане Крим після звільнення його від окупації Росією? 10.04.2018. Радіо Свобода. URL: https://www.radiosvoboda.org/a/29155093.html

14. Петришин О. Народовладдя як фундамент демократичної, правової, соціальної держави. Вісник Академії правових наук України. 2009. № 4. C. 20-30. URL: http://nbuv.gov.ua/UJRN/vapny_2009_4_3

15. Підсумки-2019 й прогнози на 2020-й: громадська думка. Загальнонаціональне дослідження Фонду «Демократичні ініціативи» імені Ілька Кучеріва спільно з соціологічною службою Центру Разумкова. 26.12.2019. URL: https://dif.org.ua/article/pidsumki-2019-gromadska-dumka

16. Пошуки шляхів відновлення суверенітету України над окупованим Донбасом: стан громадської думки напередодні парламентських виборів. Опитування Фонду «Демократичні ініціативи» ім. Ілька Кучеріва і Центру Разумкова. 11.07.2019 p. URL: http://razumkov.org.ua/napriamky/sotsiologichni-doslidzhennia/poshukyshliakhiv-vidnovlennia-suverenitetu-ukrainy-nad-okupovanym-donbasom

17. Пошуки шляхів відновлення суверенітету України над окупованим Донбасом: стан громадської думки напередодні президентських виборів. Фонд «Демократичні ініціативи» ім. Ілька Кучеріва. 13.02.2019. URL: https://dif.org.ua/article/poshuki-shlyakhiv-vidnovlennya-suverenitetu-ukraini-nad-okupovanim-donbasomstan-gromadskoi-dumki-naperedodni-prezidentskikh-viboriv

18. Ручка О. Динаміка ціннісних пріоритетів громадян України. Українське суспільство: моніторинг соціальних змін. Випуск 6 (20) / Головні редактори д.екон.н. В.М.Ворона, д.соціол.н. М.О.Шульга. К.: Інститут соціології НАН України, 2018. С. 210-215.

19. Ставлення населення до подій на Донбасі: ціна миру і шляхи подолання конфлікту. Фонд «Демократичні ініціативи» ім. Ілька Кучеріва. 13.11.2015. URL: https://dif.org.ua/article/stavlennya-naselennyado-podiy-na-donbasi-tsina-miru-i-shlyakhi-podolannya-konfliktu

20. Ставлення українців до Мінських домовленостей та статусу тимчасово окупованих територій Донецької та Луганської областей. Опитування Центру Разумкова. 01.12.2016.

URL: http://razumkov.org.ua/uploads/socio/infoDonbas1116.pdf

\section{References:}

1. 2015-j: polity`chni pidsumky` - dumka naselennya. Doslidzhennya Fondu «Demokraty`chni iniciaty`vy`» im. Il`ka Kucheriva ta Ky`yivs`kogo mizhnarodnogo insty`tutu sociologiyi. 29.12.2015.

URL: https://dif.org.ua/article/2015-y-politichni-pidsumki-dumka-naselennya

2. Bekeshkina I. Vy`rishal`ny`j 2014-j: roz'yednav chy`z'yednav Ukrayinu? Transformaciya suspil`ny`x nastroyiv v umovax proty`diyi agresiyi Rosiyi na Donbasi: regional`ny`j vy`mir / Nauk. red. O. Garan`. K.: Sty`los, 2017. S. 8-39.

3. Burakovs`ky`j I. Rosijs`ka agresiya na Cxodi Ukrayiny`yak chy`nny`k formuvannya ekonomichny`x nastroyiv v Ukrayini. Transformaciya suspil`ny`x nastroyiv v umovax proty`diyi agresiyi Rosiyi na Donbasi: regional`ny`j vy`mir / Nauk. red. O. Garan`. K.: Sty`los, 2017. S. 70-111.

4. Venislavs`ky`j F. Ideya narodovladdya v teoriyi ta prakty`ci ukrayins`kogo derzhavotvorennya (social`no-pravova cinnist` ideyi narodovladdya) // Visny`k Konsty`tucijnogo Sudu Ukrayiny`. 2011. \# 3. S. 48-56.

5. Vijna na Donbasi: realiyi i perspekty`vy`vregulyuvannya. Centr Razumkova. Proyekt «Konflikt na Donbasi: suchasni realiyi i perspekty`vy`vregulyuvannya» za pidtry`mky` MZS Niderlandiv. K., 2019. $144 \mathrm{~s}$.

6. Voyenna doktry`na Ukrayiny`. Zatverdzheno Ukazom Prezy`denta Ukrayiny` vid 24 veresnya 2015 roku \# 555/2015. URL: https://zakon.rada.gov.ua/laws/show/555/2015

7. Gajdu G. Konsty` tucijni formy` realizaciyi narodnogo volevy`yavlennya cherez referendum ta vy`borchy`j proces // Evropský politický a právní diskurz. 2018. Vol. 5. Iss. 4. P. 105-113. 
8. Gromads`ka dumka pro sy`tuaciyu na Donbasi ta shlyaxy`vidnovlennya suverenitetu Ukrayiny` nad okupovany`my` tery`toriyamy`. Opy`tuvannya Centru Razumkova. 11.10.2019.

URL: http://razumkov.org.ua/napriamky/sotsiologichni-doslidzhennia/gromadska-dumka-pro-sytuatsiiu-na-donbasita-shliakhy-vidnovlennia-suverenitetu-ukrainy-nad-okupovanymy-terytoriiamy

9. Gromads`ka dumka pro sy`tuaciyu na Donbasi ta shlyaxy`vidnovlennya suverenitetu Ukrayiny` nad okupovany`my` tery`toriyamy` (lyuty`j 2020r.). Opy`tuvannya Centru Razumkova. 26.02.2020.

URL: http://razumkov.org.ua/napriamky/sotsiologichni-doslidzhennia/gromadska-dumka-pro-sytuatsiiu-na-donbasita-shliakhy-vidnovlennia-suverenitetu-ukrainy-nad-okupovanymy-terytoriiamy-liutyi-2020r

10. Dodatkovy`j protokol do Zhenevs`ky`x konvencij vid 12 serpnya 1949 roku, shho stosuyet`sya zaxy`stu zhertv zbrojny`x konfliktiv nemizhnarodnogo xarakteru (Protokol II), vid 8 chervnya 1977 roku.

URL: https://zakon.rada.gov.ua/laws/show/995_200

11. Zakon Ukrayiny` «Pro osobly`vosti derzhavnoyi polity`ky` iz zabezpechennya derzhavnogo suverenitetu Ukrayiny` na ty`mchasovo okupovany`x tery`toriyax u Donecz`kij ta Lugans`kij oblastyax». 18.01.2018. URL: https://zakon.rada.gov.ua/laws/show/2268-19.

12. Zolkina M. Donbas: novi trendy`gromads`koyi dumky`. Transformaciya suspil`ny`x nastroyiv v umovax proty`diyi agresiyi Rosiyi na Donbasi: regional`ny`j vy`mir / Nauk. red. O. Garan`. K.: Sty`los, 2017. S. 173-198.

13. Losyev I. Yaky`m stane Kry`m pislya zvil`nennya jogo vid okupaciyi Rosiyeyu? 10.04.2018. Radio Svoboda. URL: https://www.radiosvoboda.org/a/29155093.html

14. Petry`shy`n O. Narodovladdya yak fundament demokraty`chnoyi, pravovoyi, social`noyi derzhavy`. Visny`k Akademiyi pravovy`x nauk Ukrayiny`. 2009. \# 4. S. 20-30. URL: http://nbuv.gov.ua/UJRN/vapny_2009_4_3

15. Pidsumky`2019 j prognozy` na 2020-j: gromads`ka dumka. Zagal`nonacional`ne doslidzhennya Fondu «Demokraty`chni iniciaty`vy`» imeni Il’ka Kucheriva spil`no z sociologichnoyu sluzhboyu Centru Razumkova. 26.12.2019. URL: https://dif.org.ua/article/pidsumki-2019-gromadska-dumka

16. Poshuky` shlyaxiv vidnovlennya suverenitetu Ukrayiny` nad okupovany`m Donbasom: stan gromads`koyi dumky` naperedodni parlaments`ky`x vy`boriv. Opy`tuvannya Fondu «Demokraty`chni iniciaty`vy`» im. Il`ka Kucheriva i Centru Razumkova. 11.07.2019 r. URL: http://razumkov.org.ua/napriamky/sotsiologichnidoslidzhennia/poshuky-shliakhiv-vidnovlennia-suverenitetu-ukrainy-nad-okupovanym-donbasom

17. Poshuky` shlyaxiv vidnovlennya suverenitetu Ukrayiny` nad okupovany`m Donbasom: stan gromads`koyi dumky` naperedodni prezy`dents `ky`x vy`boriv. Fond «Demokraty`chni iniciaty`vy`» im. Il kka Kucheriva. 13.02.2019. URL: https://dif.org.ua/article/poshuki-shlyakhiv-vidnovlennya-suverenitetu-ukraini-nad-okupovanimdonbasom-stan-gromadskoi-dumki-naperedodni-prezidentskikh-viboriv

18. Ruchka O. Dy`namika cinnisny`x priory`tetiv gromadyan Ukrayiny`. Ukrayins`ke suspil`stvo: monitory`ng social`ny`x zmin. Vy`pusk 6 (20) / Golovni redaktory`d.ekon.n. V.M.Vorona, d.sociol.n. M.O.Shul`ga. K.: Insty`tut sociologiyi NAN Ukrayiny`, 2018. S. 210-215.

19. Stavlennya naselennya do podij na Donbasi: cina my`ru i shlyaxy` podolannya konfliktu. Fond «Demokraty`chni iniciaty`vy`» im. Il 'ka Kucheriva. 13.11.2015. URL: https://dif.org.ua/article/stavlennyanaselennya-do-podiy-na-donbasi-tsina-miru-i-shlyakhi-podolannya-konfliktu

20. Stavlennya ukrayinciv do Mins`ky`x domovlenostej ta statusu ty`mchasovo okupovany`x tery` torij Donecz`koyi ta Lugans`koyi oblastej. Opy`tuvannya Centru Razumkova. 01.12.2016.

URL: http://razumkov.org.ua/uploads/socio/infoDonbas1116.pdf

\section{Nagornyak T. L., Zaichenko I. A. The attitude of Ukrainians to the armed conflict as a factor of system of checks and balances in the process of establishing the democracy in Ukraine}

The article attempts to scientific justification the dynamics of changes in public opinion on the conflictgenerating nature of Ukrainian reality through a system of checks and balances in the context of the formation the institution of democracy in Ukraine.

The authors' conclusions are due to the Resolution of the Verkhovna Rada №727-IX of 18.06.2020 and were based on interviews and sociological researches of Institute of sociology of NAS of Ukraine, Fund "Democratic initiatives" by Ilko Kucheriv, Razumkov Center, Kyiv International Institute of Sociology, current legislation and own experience of applied political analysis and political consulting.

The key trends in public attitudes towards armed conflict in the East of Ukraine, that are largely stable over 2014 - 2020 namely: the recognition of the "Russian factor" in the conflict, a critical assessment of national policy of Ukraine in its resolution and in socio-humanitarian work with the region, vision the future "DNR-LNR" as a part of Ukraine in the same politico-legal status as before, and, in case of impossibility of a full-scale military offensive, the willingness to compromise for the sake of a peaceful settlement. It is also proved that the armed conflict in the Donbass today does not fall in the top most important for Ukrainians problems (in contrast to 2014-2015) and tends to freeze and support the existing status quo. However, its hybridity will create a source of political instability and manipulations in Ukraine, including public opinion. It is recognized that a peaceful settlement of the armed conflict in the East of Ukraine according to the modern political situation is possible only with significant concessions of national 
interests of Ukraine. It has been proven that the institutionalization of democracy in Ukraine through a mandatory all-Ukrainian referendum, given the low level of legal awareness and empirical analysis, is premature.

Key words: public opinion, system of checks and balances, democracy in Ukraine, armed conflict, Donbass, East of Ukraine, "politics from below". 